\title{
IUPAC からの報告
}

\section{IUPAC について}

IUPAC（国際純正・応用化学連合）は，化学に関する国 際学術機関として, 化学の理解, その活用と普及に関する 学術活動を下支えする国際機関として 1919 年に設立されて 以来, その活発な活動に対して高く評価されている。 4 年 に一度開催される国際農薬学会（2006 年神戸，2010 年オー ストラリア）も Division VI（化学と環境, IUPAC の 8 つあ る Divisionの1つ）が主催する国際会議である.

\section{IUPAC の全体会議および Division VI（DCE，化学と環 境部会) の会議報告}

（於 グラスゴー 2009 年 7 月 31 日〜8 月 6 日）

\section{IUPAC 全体会議}

2 年に一度の IUPAC 全体会議 (45th General Assembly) がグラスゴーで開催され，IUPACの Division（I～VIII）, Committee【Chemrawn, COCI (化学々企業), CCE (化 学教育など】の各委員会が開かれた。また，その期間中 に第 42 回 IUPAC 世界化学大会（8 月 2 日 7 日）も開催 され，その中で，Div. VIが主催するシンポジウム“Analytical and Risk Consideration for Emerging Environmental Issues”を実施した。

な打今回の大会中に，Div. II（無機化学）の現議長を 務めて打られる巽名古屋大学教授が次期副会長に選出さ れた。副会長は会長をサポートし，その後 2012 年から 2 年間，会長を務められることが決まっている。現会長は Jin ソール大学教授で, 国連の Ban Ki-moon 事務局長之強 力な協力体制のもと，ユネスコともタイアップして，2011 年には，当年がキューリー夫人がノーベル賞を受賞して 100 年目にあたることから, “Chemistry of Year”と銘打っ て, プエルトリコで開催される第 43 回 IUPAC 世界化学 学会（2011年 7 月 30 日 8 月 7 日）をはじめとして, 各 地で大々的に “化学” の社会貢献, 可能性, 将来につい て各種イベントが企画計画されている。

\section{2. 化学と環境部会（Div. VI, DCE）の委員会報告}

\section{1 委員}

議長：Prof. Nicola Senesi（Italy), 事務局長：Dr. Willie J. G. M. Peijnenburg (Netherlands), 副議長 : Dr. Laura McConnell（USA）; TM 委員（Titular Member）：Dr. Ewa M. Cukrowska (South Africa), Dr. Petr Fedotov (Russia), Prof. Sirpa H. Herve (Finland), Prof. Nadia G. Kandile (Egypt), Prof. Werner Kördel (Germany), Dr. Keiji Tanaka
(Japan), Prof. Paul H. Wine (USA) ; AM 委員 (Associate Member) : Prof. Manos Dasseakis (Greece), Prof. Hemda Garelick (UK), Prof. Leo Klasinc (Croatia), Dr. Kenneth D. Racke（USA），Prof. Etelka Tombacz (Hungary)

2.2 プロジェクト

2008/2009 に取り組まれた，あるいは進行中のプロジェ クトは， 27 件あり， 11 件が完了， 16 件が現在進行中で ある。完了したプロジェクトの中には，片山名大教授を リーダーに取り組んできた “Bioavailability of Xenobiotics in Soil”があり，その成果はRev. Environ. Contam. Toxicol. 2010: 1-86に掲載された.

1）新しく提案のあったプロジェクト

1. A guide on the chemical recycling and management of waste.

2. Evaluation of measurement procedures and $\mathrm{QA} / \mathrm{QC}$ for $\mathrm{PCDD} / \mathrm{F}, \mathrm{PCB}$ and $\mathrm{PAHs}$ in environmental matrices (air quality, soil, sediments and wastes) used in estimation of global pollution.

3. Requirements for proficiency testing for environmental sampling.

4. AIS 15th Int. Conf. on Heavy Metals in the Environment, Gdansk, Poland, 19-23 Sept. 2010.

5. Guidance for substance-related environmental monitoring strategies.

2）最近，完了したプロジェクト：学会誌や Chemistry International に掲載

1. Bioavailability of Xenobiotics in Soil

2. Impact of Transgenic Crops on the Use and Environmental Impact of Agrochemicals

3. Global Availability of Information on Pesticides

4. A Critical Compendium of Pesticide Physical-Chemical Data

5. Simplified methods \& tools for environmental risk assessment of pesticides

6. Crop protection chemistry in Asia: harmonized approaches for safety evaluation, regulation, protection of trade

7. Crop Protection Chemistry in Latin America: Harmonized Approaches

8. Critical review of available methods to predict VOC emission potentials for pesticide formulations

9. Evaluation of food and feed safety implications of (al- 
tered) residues of pesticides applied on transgenic (GM) crops

10. Environmental risk assessments for the registration of pesticides used in rice paddy fields

11. 3rd International Workshop on Crop Protection Chemistry in Latin America: Environment, Safety, and Regulation

12. Global Availability of Information on Agrochemicals

13. Development of a Pesticide Ecological Risk Assessment and Training Module

3）最近開催された，あるいは，これから開催される IUPAC Div. VI 催のワークショップ，国際会議

1. “1st International Conference on Agrochemicals Protecting Crop, Health, and Natural Environment", Delhi, India, 8-11 January 2008.

2. "3rd IUPAC International Workshop on Crop Protection Chemistry in Latin America", Rio de Janeiro, Brazil, 9-12 November 2009.

3. "12th IUPAC International Congress of Pesticide Chemistry”, Melbourne, Australia, 4-8 July 2010.

4. "13th IUPAC International Congress of Pesticide Chemistry”（2014）：開催地は, 報告者も委員を務 める Div. VI Subcommittee で 2010 年の前半に決定 予定.

\subsection{Committee on Green Chemistry}

IUPAC の Committee の中に, Division（I， III，V，VI） の合同組織として Green Chemistry を委員会 (Committee) として設立，推進することが提案された。

最近, 化学研究者の間では, 化学物質の環境影響を意 識して, Green Chemistry が “標語”になっている感があ る. Div. VIとしては, これまで一貫して, 化学物質の環境 に対する影響の把握, その評価をベースに, 本課題に積極 的に取り組んできており, その本質一化学物質の環境負荷 軽減, 化学物質の環境影響評価法や, リスク評価法の確立 と普及，そして Sustainabilityなどーリスク低減に取り組ん できており，その経験を積極的にCommittee に反映するこ とが提起された。なお, 化学研究者の提起する Green Chemistry に対し，以下のような疑問と問題提起のあった ことを付け加えておく. 農薬の開発研究してきている農薬 関係者からすると，当たり前のことであるが...

How do you see the relationship between "Green" and "Environmental" chemistry?

Does the development of a "Green" laboratory based methodology lead to an environmental benefit (e.g. CFCs, biofuels etc.)?

What factors affect the implementation of environmentally friendly technology.?
How do we train future chemists to address these issues?

To what extent should chemists respond to socio-economic drivers towards the sustainability agenda?

\section{IUPAC Div. VI の作物保護部会（“農薬”部会）と 3rd International Workshop on Crop Protection Chemistry in Latin America の報告}

\section{1. 作物保護部会 (Subcommittee on Crop Protection} Chemistry）報告

1）作物保護部会について

IUPAC Div. VI（化学と環境）には 4つの部会（Subcommittee）があり，その中の 1 つが作物保護部会である.

1. Food Chemistry

2. Biophysico-Chemical Processes in Environmental Systems

3. Chemistry of Environmental Compartments

4. Crop Protection Chemistry（作物保護部会（“農薬” 部会)）

2）現委員

Dr. Kenneth D. Racke（委員長, USA), Prof. Irene Baptista de Alleluia (Brazil), Mr. Kevin Bodnaruk (Australia), Prof. Eloisa Dutra Caldas (Brazil), Prof. Elizabeth Carazo (Costa Rica), Dr. Wenlin Chen (USA), Prof. Jairo Arturo Guerrero Dallos (Colombia), Prof. Annemieke Farenhorst (Canada), Dr. Caroline A. Harris (UK), Prof. Horacio Heinzen ( Uruguay), Dr. Dimitrios Karpouzas ( Greece), Prof. Arata Katayama (Japan), Dr. Yong-Hwa Kim (Republic of Korea), Dr. Gijs A. Kleter (Netherlands), Dr. Jan Linders (The Netherlands), Dr. Laura McConnell (USA), Dr. Ronald Parker (USA), Prof. Gerald R. Stephenson (Canada), Dr. Keiji Tanaka (Japan), Dr. John Unsworth (UK), Dr. Sue-Sun Wong (Taiwan)

3）作物保護部会（Subcommittee on Crop Protection Chemistry）報告

於：アングラドスライス（Angra dos Reis RJ）2009 年 11 月 6 日 $~ 8$ 日

A）作物保護部会で取り組んでいる（最近完了したもの も含め) プロジェクトを，下記に列記する.

(1) Katayama, Bioavailability of xenobiotics in soil Published in Rev. Environ. Contam. Toxicol. 2010, Vol. 203 (http:// www.springer.com/environment/environmental+management/book/978-1-4419-1351-7).

土壤中の金属なども含めた環境異物の生物による Bioavailability（吸収, 活用性）について, 取り組ん だ取り組み。

(2) Kleter, Impact of Transgenic Crops on the Use and Environmental Impact of Agrochemicals. Project completed 
and reports published in Pest Manag. Sci. (2007) 63: 1107-1115 and Pest Manag. Sci. (2008) 64: 479-488. Popular articles published in Chem. Int. ( 2008) and Info. Syst. Biotechnol. (2008).

GM 作物の導入による，作物保護剤に対する影響と その結果としての環境に対する影響を評価.

(3) Carazo, Crop Protection Chemistry in Latin America: Harmonized Approaches. Nearing completion. Successful workshop of 250 attendees held in San Jose, Costa Rica during Feb-2005. Translation of the IUPAC "Pesticide Glossary" and the "Pesticides in the Environment" textbook into Spanish is nearing completion.

4 年前に中南米コスタリカで開催された第 2 回中・ 南米作物保護ワークショップのプロシーディング よ゙ の最終報告.

(4) Kleter, Evaluation of food and feed safety implications of ( altered) residues of pesticides applied on transgenic (GM) crops.

上記（2）で取り上げた GM プロジェクトの続プロ ジェクト.

(5) Unsworth, Global Availability of Information on Agrochemicals (http://www.iupac.org/web/ins/2008-041-1600) and, Wachoupe A critical compendium of pesticide physical chemistry data.

インターネットでの農薬に関する検索可能なデータ ベースの構築とその支援システムについて，企画提 案. 600 の農薬と 200 の代謝物を網羅する予定で, IUPAC の web 上で運営を前提に進めている.

(6) Alleluia, Crop protection chemistry in Latin America: Environment, safety, and regulation (3rd International Workshop).

11 月 9 日〜11 日, リオデジャネイロで開催予定の第 3 回中南米国際作物保護化学ワークショップの進渉 について説明（本ワークショップの概要は下記で報 告)

(7) Linders, Environmental risk assessments for the registration of pesticides used in rice paddy fields (http://www. iupac.org/web/ins/2006-044-2-600)

昨年, 北京で採択され議論中のプロジェクト. 水田 での農薬の運命とリスク評価に焦点を絞り，Tier I, Tier II での評価に関連して, 特に嫌気的代謝（水田 特有の情報）ついては他の土㙴中と異なることから 特に考慮することがリーダーからコメントされた。報 告者も日本での蓄積されている情報の紹介を要請さ れている.

(8) Parker, Development of a Pesticide Ecological Risk Assessment and Training Module (http://www.iupac.org/ web/ins/2008-011-2-600)

(9) Unsworth, Spray Drift Assessment and Mitigation (http://www.iupac.org/web/ins/2001-023-1-600)

(10) McConnell, Critical review of available methods to predict VOC emission potentials for pesticide formulations (http://www.iupac.org/web/ins/2006-011-1-600)

(11）新しく提案されたプロジェクト

Harris, Residues in food, human exposure-new project ideas

B）将来のワークショップ，国際会議

1）ワークショップ：インド, 中国, 中南米から 2010, 2011, 2012 にワークショップ開催の提案があり，他の 学会, ワークショップを考慮し, 現地実行委員と詳細 を詰め, 調整する.

2) 第 12 回国際農薬学会

12th IUPAC International Congress of Pesticide Chemistry in Melbourne Australia, July 4-8 2010 の進渉, 現状報告 がそして，シンポジウムの内容に関し報告があった。

3）第 13 回国際農薬学会：メルボルンの後の開催地につ いて，2010 年の前半に作物保護部会で決定し，メル ボルンでの第 12 回大会で 1st Circular をアナウンスす る.アメリカ, 中国, ブラジル等が候補地として手を 挙げている.

3）その他

日本農薬学会と米国 ACS 農薬部会と共同開催してい る PanPacific 農薬学会の中で, IUPAC としてワーク ショップやシンポジウムを共催することも可能である との提案を受けた. 本件, 報告者帰国後, 松本学会長 に伝えた。 学会長から, 学会で検討されている, 次回 PanPacific（日本が幹事）の開催案などが，米国側に 伝えられた。

\section{3rd International Workshop on Crop Protection Chemistry in Latin America}

リオデジャネイロで 2009 年 11 月 9 日〜11 日の期間, 第 3 回中南米国際作物保護化学ワークショップが開催さ れた。下記の 5 つのテーマのもと, キーノート講演, 招 待講演, ポスター発表があり, 報告者も“Innovation in agrochemical discovery and development” と題して, 日本で開 発された農薬とそれをべースに進化した農業を紹介した。

1- Innovative Chemistry and Technology for Crop Protection

2- Risk Assessment Regulation and Global Harmonization

3- Environmental Chemistry and Risk Assessment

4- Pesticides Residues in Food

5- Education and Information Management in Crop Protection 